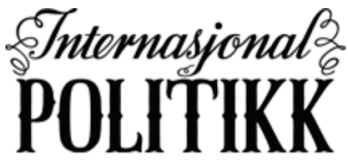

\section{Sikkerhetspolitikk, kultur eller økonomi? Konkurrerende forklaringer på omstillingen av Forsvaret etter den kalde krigen}

\author{
Håkon Lunde Saxi \\ Forsvarets høgskole / Stabsskolen, Norge
}

\begin{abstract}
Sammendrag
I 2001 besluttet Stortinget en vesentlig endring i forsvarskonsept og en betydelig reduksjon i forsvarsstrukturen. Forsvarets hovedoppgave skulle ikke lenger være å utgjøre et mobiliseringsbasert invasjonsforsvar. Beslutningen var et brudd med forsvarskonseptet som hadde dominert norsk forsvarsplanlegging under den kalde krigen og i tiåret som fulgte. Hvorfor ble invasjonsforsvaret forlatt, og hva ble Forsvarets nye hovedoppgave? Artikkelen argumenterer for at det finnes tre dominerende og delvis konkurrerende forklaringer på omleggingen av Forsvaret: en sikkerhetspolitisk, en kulturell og en økonomisk. Den første tilnærmingen ser beslutningen som drevet av et ønske om å bidra mer i utenlandsoperasjoner for å bli oppfattet som en "god alliert» i NATO og USA. Den andre forklarer overgangen med en kulturell endring der en ny og mer «internasjonalisert» forsvarspolitisks diskurs vant frem blant norske beslutningstakere. Den tredje ser endringen som et uunngåelig resultat av invasjonsforsvarets manglende økonomiske bærekraft.
\end{abstract}

Nøkkelord: forsvarspolitikk • forsvarsomstilling • årsaksforklaring • typologisering

\footnotetext{
^Kontaktinformasjon: Håkon Lunde Saxi, e-post: hsaxi@mil.no

(C)2021 Håkon Lunde Saxi. This is an Open Access article distributed under the terms of the Creative Commons Attribution 4.0 International License (http://creativecommons.org/licenses/by/4.0/), allowing third parties to copy and redistribute the material in any medium or format and to remix, transform, and build upon the material for any purpose, even commercially, provided the original work is properly cited and states its license.

Citation: Saxi, H. L. (2021). Sikkerhetspolitikk, kultur eller økonomi? Konkurrerende forklaringer på omstillingen av Forsvaret etter den kalde krigen. Internasjonal Politikk, 79(2), 190-207. http://dx.doi.org/10.23865/intpol.v79.3102
} 
I februar 2001 la Stoltenberg I-regjeringen frem St.prp. nr. 45 (2000-2001) Omleggingen av Forsvaret $i$ perioden 2002-2005. Proposisjonen la opp til en radikal omlegging av Forsvarets struktur og oppgaver. Mest oppsiktsvekkende var at proposisjonen tok et konseptuelt farvel med det mobiliseringsbaserte invasjonsforsvaret som hadde preget norsk forsvarspolitikk under den kalde krigen og i tiåret som fulgte (St.prp. nr. 45 (2000-2001), s. 32-34). Den foregående langtidsplanen - lagt frem av Bondevik I-regjeringen i februar 1998 - ble dermed den siste langtidsplanen etter den kalde krigen som holdt fast ved at Forsvarets strukturdeterminerende hovedoppgave var å utgjøre et «nasjonalt invasjonsforsvar for å møte et større militært angrep» (St.meld. nr. 22 (1997-98), s. 58).

Forsvarssjefen presenterte i juni 2000 sitt fagmilitære råd til langtidsplanen, Forsvarsstudie 2000. Studien hadde i hovedsak utredet to nye hovedinnretninger for Forsvaret, som var tenkt å erstatte invasjonsforsvaret: et "alliansetilpasset forsvar» hvor Forsvaret skulle stille norske bidrag i en alliert styrkestruktur både ut og hjemme, og et "terskelforsvar» som var en nedskalert utgave av dagens forsvar, dimensjonert for en mer begrenset trussel. Forsvarssjefens anbefalinger tok utgangspunkt i det nasjonalt orienterte terskeforsvaret (Forsvarssjefen, 2000, s. 3).

Begrepet «terskelforsvar» ble likevel aldri innarbeidet i den norske forsvarsdebatten etter 2001. St.prp. nr. 45 anvendte ingen av begrepene, og beskrev isteden det nye forsvarskonseptet i svært generelle termer som «moderne» og «fleksibelt» (St. prp. nr. 45 (2000-2001), s. 32). Den påfølgende langtidsplanen, som ble presentert i mars 2004, beskrev derimot det nye forsvarskonseptet som følger: "Forsvaret skal utvikles som et moderne, fleksibelt og alliansetilpasset sikkerhetspolitisk virkemiddel» (forfatterens utheving) (St.prp. nr. 42 (2003-2004), s. 46). Dermed var det tydelig at det var det «alliansetilpassete» alternativet som etter hvert hadde vunnet frem.

Begrepet «alliansetilpasset» ble likevel lite anvendt utenfor regjeringsdokumenter og i forsvarsbyråkratiets korridorer. I stedet festet begrepet «innsatsforsvar» seg på 2000-tallet som det vanligste utrykket brukt offentlig for å beskrive det nye Forsvaret. Begrepet «innsatsforsvar» var imidlertid uklart. Det ble først og fremst brukt for å kontrastere det «nye» Forsvaret med det "gamle» mobiliseringsbaserte invasjonsforsvaret (Bogen \& Håkenstad, 2015, s. 192-193).

Omtrent 20 år etter fremleggingen av St.prp. nr. 45 er det fortsatt ikke enighet blant forskere, beslutningstagere og i allmennheten om hvorfor invasjonsforsvaret ble forlatt som forsvarskonsept, og $h v a$ som ble konseptets erstatning. Flere overlappende forklaringer, både komplementcere og delvis konkurrerende, figurerer i forskningslitteraturen og i den offentlige debatten om norsk forsvarspolitikk. Ambisionen med denne artikkelen er å beskrive de viktigste teoretiske forklaringene på norsk forsvarsomstilling etter den kalde krigen. Jeg vil her presentere de sentrale hovedtesene om hvorfor omstillingen skjedde og hvilke oppgaver som har preget Forsvaret siden 2001. Ambisionen er å typologisere de tre mest fremtredende og toneangivende årsaksforklaringene på forsvarsomstillingen på 2000-tallet: en sikkerhetspolitisk, en kulturell og en økonomisk. 
Den sikkerhetspolitiske tilnærmingen legger vekt på hvordan Norges eksterne omgivelser formet forsvars- og sikkerhetspolitikken. Her blir drivkraften i norsk forsvarsomlegging en tilpasning av Forsvaret til det ytre trusselbildet samt forventningene fra Norges allierte. Denne tilnærmingen kan deles i to. Randstatsperspektivet legger vekt på det endrede trusselbilde i Norges nærområde, særlig den reduserte og endrede utfordringen fra stormaktsnaboen Russland. Allianseavhengighetsperspektivet tar utgangpunkt i presset fra NATO og USA om å omstille Forsvaret til å kunne stille bedre, raskere og større bidrag til internasjonale operasjoner.

Den kulturelle tilnærmingen legger vekt på at norsk forsvars- og sikkerhetspolitikk på 1990-tallet først og fremst var preget av en kontinuitet som sto i sterk kontrast til de store omveltningene som da fant sted i internasjonal politikk. Kontinuiteten blir forklart med at institusjonaliserte forsvarspolitiske forestillinger i Norge ikke endret seg i takt med de ytre rammebetingelsene. Videre blir endringen i norsk forsvars- og sikkerhetspolitikk på 2000-tallet forklart som et resultat av endringer i hvordan de sentrale aktørene i Norge oppfattet at det var legitimt og mulig å tenke og å ytre seg om norsk forsvarspolitikk.

Den økonomiske tilnærmingen legger vekt på Forsvarets store finansielle utfordringer etter den kalde krigen. Ressursene som ble bevilget var rett og slett mindre enn det som var nødvendig for å vedlikeholde og fornye Forsvaret. Dette nødvendiggjorde omstilling. Omstillingen ble særlig preget av en kvantitativ reduksjon i Forsvarets omfang og størrelse, siden de militærfaglige vurderingene var at det i liten grad var mulig å redusere kvaliteten på Forsvarets avdelinger. Endringene i Norges sikkerhetspolitiske omgivelser, forventninger fra allierte land og endringene $i$ diskursen om norsk forsvarspolitikk blir i dette perspektivet langt mindre viktig enn de underliggende økonomiske drivkreftene.

\section{Den sikkerhetspolitiske tilnærmingen: Ytre endring fremtvinger omstilling}

Den klassiske definisjonen av sikkerhetspolitikk er de tiltak en stat iverksetter for å beskytte staten, dens territorium og dens innbyggere mot et bredt spektrum av farer. Sikkerhetspolitikken legger igjen føringen for forsvarspolitikken, altså innretningen og organiseringen av landets militære forsvar. Sikkerhetspolitiske analyser av staters utenrikspolitikk innenfor internasjonal politikk har historisk sett tatt utgangspunkt i staten som en relativt enhetlig aktør som forsøker å oppnå sikkerhet eller andre sentrale målsetninger gjennom strategiske valg (se f.eks. Allison, 1969, s. 691-696). Innenfor en sikkerhetspolitisk forståelsesramme bør altså endring i det ytre trusselbildet kunne forventes å føre til forsvarspolitiske tilpasninger og endringer.

Under den kalde krigen ble hovedtrusselen mot Norge vanligvis oppfattet som et sovjetisk angrep. Dette kunne enten ta form av et videre angrep mot Vesten eller som et begrenset angrep mot deler av Norge. I 1963 ble for eksempel trusselen beskrevet som «et angrep på Norge som et ledd i et omfattende angrep på NATO-landene» eller som «et kupartet angrep på et mer begrenset område innen 
NATO» (St.meld. nr. 84 (1962-63), s. 1-2). Forsvaret var, sammen med alliert styrker, organisert og innrettet for å kunne yte sterkest mulig motstand mot en invasjon langs disse linjene.

Dersom overgangen fra «invasjonsforsvar» til «innsatsforsvar» hadde kommet like i kjølvannet av øst-vest-konfliktens bortfall, Warszawapaktens oppløsning og Sovjetunionens sammenbrudd i perioden 1989 til 1991, ville den forsvarspolitiske omleggingen sannsynligvis hovedsakelig blitt beskrevet og forklart som et resultat av disse endringene i Norges sikkerhetspolitiske omgivelser. Dette er imidlertid ikke tilfellet, siden et tiår skiller det to begivenhetene. Sammenhengen mellom dem blir derfor oppfattet som svakere.

Det finnes likevel en variant av det sikkerhetspolitiske perspektivet som betoner endringen i trusselbildet i Norges nærområde som mest avgjørende. Dette vil her bli betegnet som randstatsperspektivet (Diesen, 2000, s. 80). I dette perspektivet tilegges Norges naboskap til stormakten Russland avgiørende betydning. Her blir usikkerheten rundt den indrepolitiske utviklingen i Russland på 1990-tallet og den vedvarende maktasymmetrien mellom Norge og naboen i øst en rasjonell forklaring på norsk forsvarspolitisk konservatisme på 1990-tallet. Rundt årtusenskiftet var det imidlertid klart at Russland hadde en sterkt redusert evne og vilje til å gjennomføre en konvensjonell invasjon av norsk territorium. Likevel medførte innføringen av ny teknologi og reformer i det russiske forsvaret, i retning av mindre styrker med høyere reaksjonsevne og større kvalitet, nye sikkerhetspolitiske utfordringer for Norge. Moskva kunne tenkes å benytte disse militære kapasitetene til å anvende begrenset militærmakt mot Norge, med kort varslingstid og kort varighet, for å oppnå mer avgrensede politiske mål. Mot denne trusselen var det mobiliseringsbaserte invasjonsforsvaret, med sitt volum og utholdenhet, mindre relevant. Det var behov for mindre styrker av høyere kvalitet og med raskere reaksjonsevne - altså en styrkestruktur som hadde mange likhetstrekk med den som var påkrevd for deltagelse i internasjonale operasjoner (se f.eks. Børresen et al., 2004, s. 120-123; Saxi, 2010a, s. 61-74, 2011, s. 43; St.prp. nr. 45 (2000-2001), s. 32-46).

Randstatsperspektivet har i dag ingen dominerende stilling i debatten om å forklare norsk forsvarsomstilling på 2000-tallet, selv om mange av kritikerne av omstillingen gjerne viser til at Norges naboskap til Russland burde ha medført en større grad av kontinuitet - eller ingen omstilling overhode. Isteden domineres de sikkerhetspolitisk-orienterte årsaksforklaringene av forsvarsomstillingen av det som her vil bli beskrevet som allianseavhengighetsperspektivet. Perspektivet bygger eksplisitt eller implisitt på arbeidene og begrepsapparatet til blant annet Glenn Snyder, Rolf Tamnes og Johan Jørgen Holst.

Allianseavhengighetsperspektivets teoretiske utgangspunkt bygger på det Glenn Snyder på 1980-tallet definerte som "sikkerhetsdilemmaet i alliansepolitikken» (Snyder, 1984). Han beskriver hvordan land i en allianse må balanser mellom frykten for å bli trukket med i uønskede konflikter på grunn av alliansen (entrapment), og frykten for ikke å motta støtte fra ens allierte når man selv trenger det (abandonment). 
Utfordringen består i at forholdet mellom de to antas å stå i et invertert forhold til hverandre; et svakere engasjement $\mathrm{i}$ alliansen øker sannsynligheten for å bli forlatt; et sterkere engasjement $\mathrm{i}$ alliansen øker sannsynligheten for å bli trukket med i uønskede konflikter (Snyder, 1984, s. 466-468).

For Norges vedkommende har Rolf Tamnes beskrevet dilemmaet i norsk alliansepolitikk som en dialektikk mellom "integrasjon» og "avskjerming» - en politikk som siktet mot å binde de angloamerikanske maktene til forsvaret av Norge samtidig som man søkte å holde en viss avstand til «vestmaktene». Formålet med avskjermingen var å unngå å provosere den mektige naboen i øst samt å oppnå størst mulig innenrikspolitisk oppslutning om alliansepolitikken (Tamnes, 1987). Tamnes, dikotomi bygger igjen videre på Johan Jørgen Holsts analyse av norsk sikkerhetspolitikk vis-à-vis Moskva som en kombinasjon av "avskrekking» og «beroligelse». Hensikten var å tydeliggjøre at et sovjetisk angrep ville innebære store kostnader og høy risiko, samtidig som Norge holdt seg med flere selvpålagte nasjonale begrensninger som siktet mot å giøre status quo mer akseptabelt for Moskva (Holst, 1967, s. 31-35).

I den norske debatten om forsvarssomstillingen rundt årtusenskiftet, kan allianseavhengighetsforklaringen formuleres som følger: Norske myndigheter utviklet etter hvert en sterk bekymring for at Norge kunne bli marginalisert og forlatt om man ikke bidro tilstrekkelig til å håndtere de globale sikkerhetsutfordringene som sto i fokus i det "nye NATO» etter den kalde krigen (se f.eks. Mevik, 1999). Norge måtte gå fra å være en «sikkerhetsimportør» til å bli en "sikkerhetseksportør». Derfor ble Forsvaret omstilt til et lite "ekspedisjonskorps» og anvendt mer aktivt i krigspregede utenlandsoperasjoner fra starten av 2000-tallet. Dette skulle sikre Norge "goodwill» i NATO-alliansen generelt og i USA spesielt. De som forfekter denne årsaksforklaringen er i hovedsak kritiske til omleggingen av Forsvaret, som de hevder resulterte i en sterk allianseintegrasjon som trakk Norge inn i en rekke konflikter i utlandet (førte til entrapment). Samtidig svekket det også Norges evne til å ivareta sikkerheten hjemme og resulterte dermed også - paradoksalt nok - i en økt norsk allianseavhengighet.

To debattanter som i en årrekke har argumentert for dette synet er Jacob Børresen og Tormod Heier. Begge er offiserer som har drevet en omfattende publikasjonsvirksomhet. Heier er ansatt ved Forsvaret høyskole (FHS). Det er her viktig å poengtere at Børresen og Heier ikke tilhører den store gruppen eldre eller pensjonerte offiserer som ofte identifiseres som "tradisjonalister» eller "reaksjonære» motstandere av forsvarsomstillingen rundt årtusenskiftet (Godal, 2003, s. 65-67). Disse kritikerne publiserer sjeldent sine synspunkter skriftlig utover avisartikler, og de sliter ofte med å gi en konsistent forklaring både på hva de mener skjer og hvorfor det finner sted. Ofte blir det simpelthen slått fast, i sterkt kritiske ordelag, at omstillingen har «rasert vårt militære Forsvar» (Ebbesen, 2015). Børresen og Heier er i en annen kategori. De har over mange år publisert flere tunge forskningsarbeider som er tydelige både om hva som skjedde og hvorfor omstillingen fant sted.

Børresen har publisert en rekke bøker og artikler, men i denne sammenheng kan det være hensiktsmessig å fremheve hans debattbok Forsvar uten trussel fra 2005. 
Boken fungerer som en samling og bearbeiding av hans mange artikler, kronikker, foredrag og leserinnlegg om forsvarspolitikk. I boken kritiserer Børresen norske beslutningstakere for å følge den generelle utviklingen i Europa «bort fra store, immobile, vernepliktsbaserte territorielle forsvar og over til små, fleksible ekspedisjonskorps av høy kvalitet og med stor reaksjonsevne» (Børresen, 2005, s. 12). Han beskriver denne utviklingen som drevet av et oppfattet behov for å støtte Norges allierte i utenlandsoperasjoner. Som han uttrykte det i et senere arbeid: «Deltakelse $i$ internasjonale operasjoner under amerikansk ledelse erstattet invasjonsforsvar som Forsvarets hovedoppgave» (Børresen, 2016, s. 72). Han er kritisk fordi han mener at veivalget svekket Forsvarets evne til tilstedeværelse og forsvar av norsk territorium. Etter den kalde krigen måtte Norge, etter Børresens syn, ta et større ansvar for egen sikkerhet hjemme. Derfor var tiden «ikke inne til å bygge ned Forsvaret i det omfang og tempo som nå skjer» (Børresen, 2005, s. 14).

En lignende argumentasjon og kritikk er i de senere år blitt målbåret av Heier. I sin doktoravhandling fra 2005 argumenterer han for at norsk forsvarsstilling på starten av 2000-tallet i stor grad ble drevet frem av det amerikansk ønske om å fremme militær «transformasjon» i NATO (Heier, 2006). USAs hensikt var å giøre de europeiske allierte mer i stand til å bidra til USA-ledede ekspedisjonære operasjoner utenfor NATOs område. Heier har over flere år videreutviklet denne argumentasjonen $\mathrm{i}$ en rekke arbeider. Tidlig på 2000-tallet var han ofte positiv til retningen i reformene og kritisk til at reformene og tilpasningene ikke gikk langt nok (Heier, 2000a, 2000b). Han har imidlertid i de siste årene blitt stadig mer kritisk til «de politiske valg og vurderinger som ble gjort på slutten av 1990-tallet og på begynnelsen av 2000-tallet, da myndighetene [...] avviklet det territorielle forsvaret for å oppfylle amerikanske forventninger i NATO" (Heier, 2019, s. 63). Resultater, hevder han, er blitt "et vakuum [i nordområdene] som raskt fylles av USA» (Heier, 2019, s. 102). Særlig kritiserer han at denne utviklingen «har ført til en sterkere avhengighet til USA" (Heier, 2019, s. 99). Etter hans syn er resultatet blitt mindre "avskjerming» i forhold til NATO og USA og dermed også mindre «beroligelse» av Russland. Resultatet har vært negativt for norsk sikkerhet. Russiske mottiltak mot økt amerikansk tilstedeværelse fører, slik Heier ser det, til at «Norge får mindre sikkerhet fremfor mer» (Heier, 2019, s. 183).

Børresen og Heier er grunnleggende kritiske til det de oppfatter som hovedfokuset på utlandsoperasjoner i forsvarsreformen. Det er imidlertid ikke alle som vil si seg enige i påstanden om at dette var et feilgrep. Den norske diplomaten Leif Larsen er et eksempel på en som ser forsvarsomstillingen som drevet frem av sikkerhetspolitiske årsaker, men som samtidig argumenterer for at denne utviklingen var både ønskelig og nødvendig. Larsen beskriver omstillingen som en overgang fra «et mobiliseringsbasert territorialforsvar til vervede ekspedisjonsstyrker med stor mobilitet og høy reaksjonsevne» (Larsen, 2011, s. 24). Han er opptatt av behovet for å "kjøpe» alliertes oppmerksomhet, men argumenterer også for at fjerne konflikter påvirker norsk sikkerhet. «Trusselbildet var radikalt endret» av krigene på Balkan og 
terrorangrepet på USA 11. september 2001, noe som igjen gjorde at «grunnleggende endringer i forsvarsstrukturen var tvingende nødvendig»(Larsen, 2011, s. 30).

Allianseavhengighetsperspektivet har de siste årene fått sterkt gjennomslag i det offentlige ordskiftet i Norge, langt ut over rekkene til pensjonerte offiserer og andre tradisjonelle «forsvarsvenner». Perspektivet er stadig oftere å gjenfinne blant lederartikler i landets fremste aviser, i kronikker samt i intervjuer med stortingsrepresentanter og andre offentlige personer. Med andre ord står dette perspektivet stadig sterkere i samfunnsdebatten.

Et nylig eksempel kom da den tidligere redaktøren i Aftenposten Harald Stanghelle i 2019 skrev at Forsvaret etter den kalde krigen var blitt offer for «en omlegging som viste seg å være en nedbygging» drevet frem av behovet for å kunne delta $\mathrm{i}$ «spisse utenlandsoperasjoner». Stanghelle var særlig kritisk til at ingen "generaler eller politikkere» etterpå var villige til å påta seg ansvaret for denne utviklingen, som han derfor karakteriserte som en «ansiktsløs feil» (Stanghelle, 2019, s. 12-13).

Stanghelles artikkel er et symptom på at en nærmest konspiratorisk tolkning av forsvarsreformene på 2000-tallet, som lenge hadde eksistert i mer perifere deler av debatten, er i ferd med å bli «mainstream». Lignende argumenter hadde i en årrekke blitt fremført av kritikere av NATO og USA på venstresiden, samt på høyresiden av det som er blitt karakterisert som et lite og «nasjonalkonservativt miljø» som var opptatt av forsvarsspørsmål (Børresen et al., 2004, s. 142). Denne løst sammensatte «nasjonalkonservative» grupperingen kan sammenlignes med den større og mer profilerte bevegelsen på 1940- og 50-tallet, da disse grupperingene sto for et tradisjonelt og nasjonalt orientert forsvar og mot deltagelse i utlandet (Skogrand, 2004, s. 327-330).

Som en kontemporær representant for et slikt nasjonalkonservativt syn på forsvarspolitikken kan man trekke frem samfunnsdebattanten Øystein Steiro Sr. I 2006 tordnet han mot forsvarssjef Sverre Diesen og påsto at det pågikk «en styrt avvikling av hele Forsvaret» (Steiro, 2006). Steiro hadde ikke endret syn i 2019, da han skrev at det var «ikke noe mindre enn en nasjonal skandale» hvordan Forsvaret var blitt bygget ned til «noen få høyteknologiske og kostbare mobile kapasiteter egnet til utenlandsoppdrag». Forsvarsreformens sikkerhetspolitiske forutsetninger var, ifølge Steiro, «grunnleggende feil» (Steiro, 2019).

Kritikken mot den oppfattede omdannelsen av Forsvaret til et lite «ekspedisjonskorps» som både umoralsk og som et sikkerhetspolitisk feilgrep sto og står likevel særlig sterkt på den politiske venstresiden i Norge. Et eksempel er tidligere stortingsrepresentant for Sosialistisk Venstreparti Stein Ørnhøi. I $2016 \mathrm{skrev}$ han at Norge etter forsvarsreformene på 2000-tallet hadde utviklet «en hær med spisskompetanse på krig i Afghanistan, et luftforsvar med store ferdigheter når det gjelder å utslette arabiske byer og ikke minst et sjøforsvar [...] som har langt flere seilingsdøgn i Middelhavet og Adenbukta enn i Norskehavet» (Ørnhøi, 2016, s. 132). Som et resultat av dette hevdet han at forsvarspolitikken var «havnet i et dramatisk uføre» (Ørnhøi, 2016, s. 138). 
Allianseavhengighetsperspektivet har, foruten hos Børresen og Heier, en svak stilling i den akademiske debatten om norsk forsvarsomstilling i Norge. Til gjengjeld har perspektivet fått et stadig sterkere fotfeste i det offentlige ordskiftet. Årsaken er kanskje det strategiske sjokket Vesten opplevde i kjølvannet av Russlands annektering av deler av Ukraina i 2014. Det syntes å underbygge oppfatningen om at forsvarsreformen må ha bygget på strategiske feilslutninger.

Ukraina-krisen og andre hendelser gjordet det klart at Norge og NATOs ønske om å få til «et genuint strategisk partnerskap» med Russland hadde slått feil (NATOs stats- og regjeringssjefer, 2010, s. 29). Krisen forverret trusselbildet i Norges nærområder og gjorde det klart at væpnede konflikter og andre former for militær maktanvendelse mot Norge på ingen måtte kunne utelukkes. Utviklingen er fra NATOs hold blitt møtt med «den største forsterkningen av vårt kollektive forsvar siden den kalde krigen» (NATO, 2017, s. 6). Fra norsk side har den blitt møtt med et langt sterkere fokus på å etablere en troverdig norsk avskrekking og forsvarsevne med basis i NATOs kollektive forsvar (se f.eks. Prop. 62 S (2019-2020), s. 17-31).

\section{Den kulturelle tilnærmingen: Framveksten av en ny «representasjon» fører til omlegging}

De ovennevnte sikkerhetspolitiske tilnærmingene tar utgangspunkt $i$ at forsvarspolitiske veivalg er et resultat av statens forsøk på å oppnå sikkerhet (eller andre sentrale målsetninger). Beslutningene kan være riktige eller uriktige, men de er drevet av statens antatte - og mer eller mindre - objektive interesser. En alternativ tilnærming til å forklare norsk forsvarspolitikk er det som her vil bli omtalt som kulturperspektivet. Denne tilnærmingen utfordrer antagelsen om at forsvarspolitikken handler om rasjonell atferd (noen ganger omtalt som en «rasjonalistisk tilnærming»). Isteden er forsvarspolitikken et resultat av identitet, språk, verdier og veletablerte forestillinger. Kampen om forsvarspolitikken handler ikke om statens interesser, men om definisjonsmakten i forsvarsdebatten.

En slik måtte å se på kontinuitet og endring i norsk forsvarspolitikk bygger på det som kalles "de nye kulturstudiene» innenfor human- og samfunnsvitenskapene, med utspring i den strukturalistiske og poststrukturalistiske tradisjonen (Jordheim, 2010). Særlig Michel Foucaults og Ferdinand de Saussures diskursbegrep har vært sentrale referanser innenfor denne tilnærmingen, som gjerne har blitt betegnet som "konstruktivisme», "poststrukturalisme» eller "postmodernisme».

Iver B. Neumann er her en sentral aktør, som på 1990-tallet bidro til å bygge opp et samfunnsvitenskapelig forskningsmiljø ved Norsk Utenrikspolitisk Institutt (NUPI), forankret i konstruktivismen/poststrukturalismen (Bratberg, 2019). Sammen med NUPI-kollega Ståle Ulriksen brakte Neumann disse perspektivene, med sitt fokus på identitet og sosial strukturer, inn i debatten om norsk forsvarspolitikk (Græger, 2019).

Neumann og Ulriksen var på 1990-tallet kritiske til den manglende omleggingen i norsk forsvarspolitikk, som de oppfattet som nærmest totalt fokusert på forsvaret av 
norsk territorium og «rest-trusselen» fra Russland. Den avgjørende årsaken til dette, ifølge dem, var ikke grunnet i beslutninger tatt på bakgrunn av strukturen i internasjonal politikk, de materielle maktforholdene i verden og det resulterende trusselbildet mot Norge. Årsaken var i stedet en konstruert norsk «forsvarstradisjon» som var «ensidig fokusert på forsvaret av norsk territorium forstått som sammenhengende landterritorium» (Neumann \& Ulriksen, 1997a, s. 119).

Neumann og Ulriksen utviklet sine argumenter i antologien Norges utenrikspolitikk fra 1997 samt i Norsk Militert Tidsskrift (Neumann \& Ulriksen, 1997a, 1997b). Hovedverket innenfor denne «kulturelle» tilnærmingen var likevel Ulriksens bok Den norske forsvarstradisjonen: Militcermakt eller folkeforsvar? (Ulriksen, 2002). «Forsvarstradisjonen» ble her definert som «et sett av oppfatninger, holdninger, verdier og vurderinger» som "[t]il sammen danner [...] en bestemt forståelse av hva Forsvarets rolle i Norge har vært, er og bør være» (Ulriksen, 2002, s. 267).

Ifølge Ulriksen var forsvarspolitikken under den kalde krigen og på 1990-tallet i stor grad uavhengig av utenriks- og sikkerhetspolitikken. Den var isteden bestemt av behovet for å anvende Forsvaret som et instrument for nasjonsbygging, en funksjon der særlig den allmenne verneplikten sto sentralt. Forsvaret valgte derfor «en strategi tilpasset verneplikten»(Ulriksen, 2002, s. 228), med fokus på en defensiv forsvarskamp på norsk territorium, kvantitet over kvalitet, Hæren og Heimevernet fremfor Sjøforsvaret og Luftforsvaret, og den enkelte soldats individuelle ferdigheter og forsvarsvilje fremfor velfungerende og samtrente avdelinger.

Mens representantene for den ovennevnte «sikkerhetspolitiske tilnærmingen» ofte har kritisert omleggingen av Forsvaret siden starten av 2000-tallet, var forskningsmiljøet ved NUPI på 1990-tallet og starten av 2000-tallet kritisk til det det de oppfattet som en utilstrekkelig grad av endring og tilpasning av norsk forsvarspolitikk etter den kalde krigen. De hevdet at forsvarspolitikken og Forsvaret utviste en for stor grad av kontinuitet og var utilstrekkelig «internasjonalisert» på 1990-tallet (Græger, 2009). Sentrale kritikere innen denne tilnærmingen er Ståle Ulriksen, Iver B. Neumann, Nina Græger, Halvard Leira, Karsten Friis og senere utenriks- og forsvarsminister Espen Barth Eide. Grægers doktoravhandling, Norsk forsvarsdiskurs 1990-2005: Internasjonaliseringen av Forsvaret, er kanskje det arbeidet som klarest bygget videre på Ulriksens og Neumanns prosjekt (Græger, 2007; se også Græger, 2016).

Ulriksen og Neumann var på 1990-tallet tydelige på at de mente at «tiden er kommet for å legge Forsvaret radikalt om [...] og tilpasse dette til situasjonen og behovene etter den kalde krigen» (Neumann \& Ulriksen, 1997b, s. 46). Særlig var de opptatt av at Forsvaret måtte bli et relevant utenrikspolitisk maktinstrument for Norge. Ulriksen hevdet at Forsvaret på 1990-tallet forble «en slags fasade» heller en «et seriøst militært apparat [...] Forsvaret var bare i liten grad et effektivt instrument for bruk av tvangsmakt utad" (Ulriksen, 2002, s. 241). Årsaken til at endringsforslag ble møtt med sterk motstand var $i k k e$ uenigheter om det ytre trusselbilde, men indrepolitiske forhold i Norge, som identitet, språk og ideer. 
Ulriksens hovedforklaring var «den norske forsvarstradisjonens» betoning av det direkte forsvaret av norsk landterritorium gjennom allmen verneplikt. Det ga begrenset rom for å giøre Forsvaret til et anvendelig instrument for norsk utenrikspolitikk (Neumann \& Ulriksen, 1997a; Ulriksen, 2002). I denne forbindelse har Espen Barth Eide pekt på hvordan norske offiserer og befalsorganisasjoner var sterkt kritiske til å bli pålagt beordringsplikt til internasjonale operasjoner, noe som igjen demonstrerer selvforståelsen i Forsvaret, som forsvarere av norsk territorium (i snever forstand) (Eide, 1995, s. 198-199). Halvard Leira har argumentert for at den videre «norske fredsdiskursen» gjorde det generelt utfordrende å få aksept i det norske samfunnet for bruk av militære virkemidler i utenrikspolitikken, fordi "de som i dag forsøker å få aksept for en mer aktiv bruk av norsk millitærmakt, forstyrrer nemlig en viktig del av norsk selvforståelse» (Leira, 2004, s. 180). På samme vis peker Karsten Friis på at det var vanskelig for skiftende norske regjeringer å legitimere militær maktbruk i utenlandsoperasjoner med norske sikkerhetsbehov. Selv etter omleggingen av Forsvaret på starten av 2000-tallet var begrunnelsene gjerne humanitære og ideelle. Maktbruken ble samtidig forsøkt nedtonet så mye som mulig (Friis, 2006, s. 110-112).

Fellestrekket med disse tilnærmingene var at de forklarte forsvarspolitikken hovedsakelig som skapt av indre ikke-materielle faktorer som "sosiale relasjoner, meningsdannelse, identitet og institusjoner» (Græger, 2009, s. 355). Men hvordan forklarer så sosialkonstruktivistene og poststrukturalistene omleggingen av forsvarspolitikken og Forsvaret etter 2001?

Hovedforklaringen representantene for den kulturelle tilnærmingen gir på omleggingen, er at en ny «representasjon» av forsvarspolitikken vant frem omtrent samtidig som det fant sted et generasjonsskifte. Leira og Græger beskrev for eksempel i 2005 overgangen som en seier for en ny «representasjon» av virkeligheten over den gamle «representasjonen». Bærerne av den "gamle» forsvarspolitiske diskursen ble gradvis marginalisert av bærerne av den "nye» diskursen. Denne overgangen inneholdt "et visst element av generasjonsendring", da mange av de som identifiseres som bærerne av den "nye diskursen» var yngre enn sine motstandere (Græger \& Leira, 2005, s. 56-57).

Ståle Ulriksen gir en lignende forklaring. Han betegnet i 2007 omleggingen på 2000-tallet som «et brudd med fortiden, et paradigmeskifte i norsk forsvarspolitikk (Ulriksen, 2007, s. 144). Årsaken til at omleggingen ble mulig var, etter hans syn, ikke at motstanderne ble omvendt, men at de døde ut eller ble marginalisert. «De sterkeste forkjemperne for forsvarstradisjonene ble stemplet som 'dinosaurer', og de har tilsynelatende mistet meget av sin kraft» (Ulriksen, 2007, s. 147). En lignende forklaring gis av den norske journalisten og offentlige debattanten Aslak Nore, som beskriver kampen om forsvarspolitikken på 1990-tallet som "en generasjonskløft». «På den ene side sto 'forsvarsvenner' og skriveføre pensjonerte offiserer som krevde slutt på at norsk personell ble sendt i utenlandstjeneste mens territorialforsvaret forvitret. På den andre siden sto moderniseringvillige byråkrater og den yngre generasjonen 
offiserer» (Nore, 2007, s. 214). Konflikten ble, ifølge Nore, etter hvert et tilbakelagt stadium ettersom «krigsgenerasjonene var utdøende, de kalde krigerne hadde gått av med pensjon» (Nore, 2007, s. 214).

En utfordring for de såkalte «nye kulturstudienes» bruk av diskursanalyse som teori og metode, er at de ofte sliter med å gi en god forklaring på diskursive endringer (Jordheim, 2010). Det gjelder også norsk forsvars- og sikkerhetspolitikk, der den kulturelle tilnærmingen gir en bedre og mer overbevisende forklaring på kontinuiteten på 1990-tallet enn på endringene og omleggingen på 2000-tallet. Vi får ikke noe tilfredsstillende svar på hvorfor den gamle "forsvarstradisjonen» ikke ble reprodusert hos den yngre generasjonen med forsvarsbyråkrater, akademikere og offiserer. Det er også interessant å merke seg at denne tilnærmingen har fått stadig mindre plass i debatten om norsk forsvarspolitikk etter omstillingen på 2000-tallet.

Likevel fanger tilnærmingen noe essensielt: Den gir innsikt i den sterkt følelsesladede debatten om norsk forsvarspolitikk etter den kalde krigen, som gikk langt ut over konkrete uenigheter om det «objektive» ytre trusselbildet og norske interesser. Debatten handlet også om langt mer fundamentale forhold som angikk debattantenes verdensanskuelse, identitet, selvfølelse og selvbilde.

\section{Den økonomiske tilnærmingen: Økonomisk press fremtvinger endring}

Den sikkerhetspolitiske tilnærmingen vektlegger de ytre og (primært) materielle rammebetingelsene for norsk forsvarspolitikk, mens den kulturelle tilnærmingen vektlegger de indre og ikke-materielle forholdene. Den økonomiske tilnærmingen skiller seg fra begge disse ved at man her legger mest vekt på de indre og materielle forutsetningene for norsk forsvarspolitikk.

Tesen om at det er økonomiske drivkrefter som har forårsaket omstillingen av Forsvaret har sin mest markerte forsvarer i Sverre Diesen. I kraft av sin sentrale rolle i utarbeidelsen av Forsvarsstudie 2000 og senere som forsvarssjef (2005-2009) har han både vært en sentral aktør, premissleverandør og også en svært viktig analytiker av norsk forsvarspolitikk. Diesen har over flere årtier vært en aktiv skribent og debattant. Mye av hans argumentasjon om Forsvarets utvikling er samlet i boken Fornyelse eller forvitring? Forsvaret mot 2020 (Diesen, 2011).

Diesens sentrale poeng er at det gamle mobiliseringsbaserte invasjonsforsvaret var avleggs etter den kalde krigen, både av sikkerhetspolitiske og samfunnsmessige årsaker, men særlig på grunn av kostnads- og teknologiutviklingen. Disse faktorene gjorde det «økonomisk umulig å utruste et stort mobiliseringsforsvar og [skapte] kompetansekrav som ikke kan innfris i mobiliseringsenheter med sporadiske repetisjonsøvelser» (Diesen, 2011, s. 66). For Diesen fremstår St.prp. nr. 45 derfor ikke som et valg, men som fullbyrdingen av en «økonomisk nødvendighet» (Diesen, 2011, s. 24).

Den økonomiske forklaringen på omstillingen rundt årtusenskiftet fikk også sterk støtte fra de kvantitativt orienterte forskningsmiljøene ved Forsvarets 
forsvarsinstitutt (FFI). Forskningsmiljøene ved FFI hadde både innsikt og innflytelse i forsvarspolitikken, fordi de siden 1960-tallet hadde levert viktige deler av det økonomiske, strategiske og strukturelle grunnlagene for Forsvarets langtidsplanlegging (Njølstad \& Wicken, 1997, s. 310-360). Som en del av dette arbeidet gjennomførte FFI i 1993 en studie av materiellbeholdningen til Hærens mobiliseringsavdelinger. Studiene viste at materiellet i 1992 bare ville ha vært tilstrekkelig til å utruste tre av Hærens 13 brigader (Johnsen et al., 1993, s. 54-55). Rapporten ble først typisk nok gradert, men ble senere nedgradert og offentligjort i 2005.

Administrerende direktør ved FFI, Paul Narum, trakk i 2005 frem rapporten som bevis på at Forsvarets omstilling på 2000-tallet ikke primært handlet om sikkerhetspolitikk. «Mange som deltar i den pågående forsvarsfaglige og -politiske debatten, ser den økte vektleggingen av internasjonale operasjoner som årsaken til volumreduksjonene. Dette er ikke riktig» (forfatterens uthevning) (Narum, 2005). Årsaken til at mange misforsto årsaksforholdene var, ifølge Narum, at verken offentligheten eller offiserskorpset fullt ut forsto hvor graverende manglene i det gamle mobiliseringsforsvaret hadde vært. Dette skyldtes dels at forholdene var graderte, og dels at kun en liten del av Hæren ble mobilisert ved øvelser.

Narum holdt frem tre hovedårsaker til omstillingen rundt årtusenskiftet: forsvarsbudsjettets stadig synkende kjøpekraft, bortfallet av den amerikanske våpenhjelpen på 1960-tallet, som likevel frem til 1980-tallet "ga rom for en vesentlig større forsvarsstruktur [...] enn vi selv på sikt kunne betale for», og til sist, at Forsvaret nå faktisk ble anvendt i løpende operasjoner. Det siste bidro til å synliggjøre mangler i Forsvarets materiell og struktur på en annen måtte enn under den kalde krigen (Narum, 2005). I sum argumenterte FFI-forskerne for at den tilsynelatende enorme volumreduksjonen etter den kalde krigen -i Hæren fra 13 brigader 1990 til en stående brigade og (i teorien) en mobiliseringsbrigade i 2004 (St.prp. nr. 42 (2003-2004), s. 62-63) - i realiteten var mye mindre. Mange av brigadene hadde i realiteten lenge vært "papirbrigader». Det var oppdagelsen av svært mange slike misforhold mellom teori og virkelighet som i 2000 fikk det regjeringsoppnevnte forsvarspolitiske utvalget til å konkludere med at «idéen om et nasjonalt balansert forsvar finnes bare $\mathrm{i}$ retorikken» og at det nå var behov for «radikal omlegging» (utheving original) (NOU 2000: 20, s. 26-27).

Som nylig avgått forsvarssjef i 2010 bruke Sverre Diesen anledningen til å reflektere over sine fire år ved roret til å forsøke å rydde opp i årsaksforklaringene rundt forsvarsomstillingen på 2000-tallet. Diesen kritiserte den analytiske sammenblandingen som ofte forekom mellom endringen i Forsvarets innretning, som skyldtes sikkerhetspolitiske endringer etter den kalde krigen, og den store reduksjonen i Forsvarets volum. Siden disse to utviklingene sammenfalt i tid, ble de ofte blandet sammen, men ifølge Diesen var de "uavhengig av hverandre i årsak» (Diesen, 2010). Han argumenterte med andre ord for at reduksjonen i Forsvarets volum ville kommet uansett, uavhengig av den sikkerhetspolitiske omveltningen. 
De fleste vil i dag være enige i Diesens argumenter om at økonomiske forhold framtvang en betydelig reduksjon i Forsvarets volum etter den kalde krigen. Mer kontroversielt var hans videre argument om implikasjonene av dette for Forsvarets innretning. Diesen hevdet allerede i 1999 at volumreduksjonen nødvendiggjorde et bortfall av invasjonsforsvaret, siden Forsvaret var i ferd med å bli redusert til en størrelse "som gjør at det ikke lenger vil være meningsfylt å snakke om et nasjonalt forsvar i forhold til en tradisjonell invasjonstrussel» (Diesen, 1999, s. 6). Som han utrykte det året etter: "Økonomien setter [...] klare grenser for hvor stort Forsvaret da kan bli, og uansett kan vi fastslå at det blir lite - så lite at det vil være helt utilstrekkelig for den type invasjonsscenario som vi tok utgangspunkt i under den kalde krigen» (Diesen, 2000, s. 89). Slik sett mente også Diesen, når alt kom til alt, at endringen i Forsvarets innretning også var et resultat av økonomisk nødvendighet.

Det «Diesenske» perspektivet på forsvarets omstilling fikk i 2015 sitt tyngste forskningsmessige bidrag i boken Balansegang: Forsvarets omstilling etter den kalde krigen, skrevet av historikerne Olav Bogen og Magnus Håkenstad ved FHS (Bogen \& Håkenstad, 2015). De argumenterer for at det er de økonomiske utfordringene «som har spilt selve hovedrollen» i norsk forsvarsomstilling etter den kalde krigen (Bogen \& Håkenstad, 2015, s. 344). «Satt på spissen» var bokens sentrale forskningsmessige påstand at de "økonomiske ubalansene [i Forsvaret] alene var store nok til at omfattende strukturreduksjoner og effektiviseringsgrep ville ha vært tvingende nødvendig uavhengig av den sikkerhetspolitiske utviklingen» (Bogen \& Håkenstad, 2015, s. 344).

Bogen og Håkenstad var særlig uenige i påstanden om at det var behovet for å tilpasse Forsvaret til endrede ytre omgivelser og press, som behovet for å bidra mer på Balkan og i Afghanistan, eller for å svare på amerikanske reforminitiativer i NATO, som var den sentrale driveren for omstillingen. Disse faktorene påvirket retningen og tempoet i reformene, men den sentrale årsaken var Forsvarets økonomiske og strukturelle ubalanse (Bogen \& Håkenstad, 2015, 2017). De hevdet at «den iboende forsvarskonservative tendens» i Norge var så sterk at "den sikkerhetspolitiske utviklingen alene neppe hadde utvirket dyptgripende endringer dersom forsvarsstrukturen hadde vært økonomisk bærekraftig» (Bogen \& Håkenstad, 2015, s. 344-345).

Særlig de som benektet kaldkrigsforsvarets store utfordringer hva angikk bærekraft ble kritisert av de to FHS-forskerne. I disse fremstillingene ble debatten om forsvarsomstillingen gjerne til et «kriminalmysterium der [det] gjelder å finne morderen». Bogen og Håkenstad kritiserte videre påstanden fra tilhengerne av allianseavhengighetsperspektivet om at Forsvaret ble bygget ned på 2000-tallet først og fremst for å konsentrere seg om internasjonale oppgaver. Som de skrev i et svar til Stanghelle: «Forsvaret forlot aldri hjemmeoppgavene. Mens norske soldater sloss i Afghanistan, gikk de store summene og mye av oppmerksomheten til å styrke Forsvaret på hjemmebane [...] Norsk strategi er først og fremst preget av kontinuitet» (Bogen \& Håkenstad, 2019). Nyere studier av norske forsvarsutgifter synes å styrke 
bildet av at hovedtyngden av Forsvarets virksomhet, også etter omleggingen rundt årtusenskiftet, var knyttet til hjemmeoppgavene heller enn til deltagelse i internasjonale operasjoner (Hilde, 2020, s. 20-21).

\section{Avslutning}

Hensikten med denne artikkelen har vært å være typologiserende, altså å utvikle en inndeling av et materiale i karakteristiske typer. Artikkelen deler debatten om årsakene og formålet med norsk forsvarsomstilling etter den kalde krigen inn $\mathrm{i}$ tre distinkte perspektiver med ulike syn på årsakene til omstillingen.

Perspektivene er ikke nødvendigvis giensidig utelukkende. De kan utfylle og komplementere hverandre (se f.eks. Saxi, 2010a, 2010b, 2011). Rones (1995) viser at utfylling og samening er mulige strategier for å håndtere teorimangfold i samfunnsvitenskapene. Forsvarsomstillingen vil da bli forklart som et samspill mellom forklaringselementer hentet fra ulike teorier. En slik utfyllingsstrategi har den fordel at den kan gi større forklaringskraft, men på bekostning av klarheten, knappheten og den indre konsistensen i forklaringen. Andre strategier Rones foreslår for å håndtere teorimangfold er avskjerming eller konkurrering. Fordelene er at dette produserer klarere, mer konsise og internt konsistente forklaringer, men muligens på bekostning av gyldighet og realisme.

Perspektivmangfoldet $\mathrm{i}$ forsvarsdebatten kan sies å ha bidratt til å berike og mangfoldiggjøre både forskningslitteraturen og det offentlige ordskiftet. Perspektivene bygger for eksempel delvis på ulike ontologiske og epistemologiske posisjoner. Videre vil svært mange som har beskjeftiget seg med norsk forsvarsomstilling etter den kalde krigen være enige i at både sikkerhetspolitikk, kultur og økonomi har spilt en rolle. Det må likevel være legitimt å stille spørsmålet: Hvilket av perspektivene har størst forklaringskraft? Dette spørsmålet blir særlig sentralt da hovedtendensen i forsvarsdebatten, som vist i artikkelen, er avskjerming eller konkurrering fremfor utfylling og samening. Påstandene om hovedårsaken til omstillingen, som presenteres innenfor hvert perspektiv, utelukker gjensidig hverandre.

En måte å si noe om perspektivenes relative forklaringskraft er å ta mål av hvor sterkt perspektivene står i dagens vitenskapelige og samfunnsmessige debatt om forsvarsomstillingen. Allianseavhengighetsperspektivet har siden starten av 2000-tallet fått en sterk stilling i den offentlige debatten om grunnlaget for forsvarets omstilling. Det står særlig sterkt blant ikke-eksperter som søker å gi en kort og konsis forklaring på forsvarsomstillingen. Perspektivet har samtidig en noe svakere stilling $i$ den akademiske debatten. De som legger avgjørende vekt på denne årsaksforklaringen, som Børresen og Heier, tenderer til å betrakte omleggingen kritisk - som et feilgrep. De betviler ikke at beslutningstakerne handlet formålsrasjonelt, med mest mulig sikkerhet for Norge som mål, men avveiningen mellom nasjonal og internasional innsats ble likevel feil. Randstatsperspektivets søkelys på den endrede utfordringen fra Russland blir generelt ignorert av offentligheten, og får lite oppmerksomhet selv hos 
mange forsvarseksperter. De som anvender dette perspektivet, er ofte beslutningstakerne selv. Randstatsperspektivet trekkes gjerne frem for å tilbakevise påstander fra tilhengerne av allianseavhengighetsperspektivet, som for eksempel at forsvarsreformene etter årtusenskiftet bygget på antagelsen om at «krig i våre nærområder kan utelukkes» (se f.eks. Frantzen, 2006).

Kulturperspektivet sto på 1990- og 2000-tallet sterkest blant akademikere, særlig en gruppe statsvitere ved NUPI som forsket på utenriks-, sikkerhets- og forsvarspolitikk. Enkelte politikere og praktikere som ønsket omlegging, la også vekt på at motstanden skyltes kulturelle faktorer. Perspektivet har imidlertid fått mindre plass i debatten etter 2000-tallet, noe som kan tyde på at det var mer egnet til å forklare (og kritisere) kontinuiteten på 1990-tallet enn til å forklare omleggingen etter årtusenskiftet. Perspektivet synes å ha mindre å tilføre debatten i dag. I sum ønsket mange av kulturperspektivets tilhengere en mer «internasjonalisert» bruk av Forsvaret. De var og er derfor generelt positive til omleggingen rundt årtusenskiftet. Det som skiller dem sterkest fra de mer «rasjonalistiske» tilnærmingene er imidlertid deres ontologi og epistemologi. Kulturperspektivet skiller seg altså ut både når det gjelder hva som studeres og hvordan fenomenet studeres. Tilnærmingen bygger på en større grad av «refleksivitet», der aktørenes formålsrasjonalitet i langt mindre grad tas for gitt og der menneskelig subjektivitet, verdier, normer og praksiser blir tillagt større forklaringskraft (Keohane, 1988).

Økonomiperspektivet har stått sterkest blant sivile og enkelte militære eksperter. De understreker at Forsvarets tilsynelatende dramatiske kvantitative nedbygging var uunngåelig, siden forsvarsstrukturen som invasjonsforsvaret bygget på ikke var økonomisk bærekraftig. Her vil også mange ikke-eksperter kunne si seg enige, selv om det eksisterer miljøer, som deltar i det offentlige ordskiftet både fra høyre- og venstresiden, der dette $i k k e$ blir akseptert. Mer omstridt er påstanden om at økonomiske drivkrefter også nødvendiggjorde et nytt forsvarskonsept. Kunne man ikke bare fortsatt med en nedskalert utgave av den kalde krigens mobiliseringsbaserte invasjonsforsvar? Økonomiperspektivets fremste tilhengere mener at dette ikke var mulig, og at det sikkerhetspolitisk heller ikke var ønskelig. Likevel er det tenkelig at Norge kunne valgt å gjøre som Finland: å beholde et nedskalert mobiliseringsbasert invasjonsforsvar. Til tross for et mindre forsvarsbudsjett enn Norge, har Finland i dag en krigsstyrke etter mobilisering på 285000 soldater, hvorav de fleste inngår i den finske hærens ni brigader og fire bataljonsstridsgrupper (Frisell et al., 2018, s. 61-69). Det synes derfor sannsynlig at det var økonomisk mulig for Norge å ende opp med en større hær enn dagens ene stående mekaniserte brigade, selv innenfor et «alliansetilpasset» forsvarskonsept.

Å demonstrere at det i forskningslitteraturen og samfunnsdebatten om norsk forsvarsomstilling finnes flere identifiserbare perspektiver på årsakene til omstillingen har vært denne artikkelens hovedformål. Da perspektivene er mer konkurrerende enn komplementære, har deres relative forklaringskraft også blitt adressert. Perspektivmangfoldet har beriket forsvarsdebatten, samtidig som den har gjort den 
mer krevende å overskue. Gjennom en tredelt typologisering av de mest toneangivende forklaringene på forsvarsomstillingen bidrar denne artikkelen til å tydeliggjøre dagens forskningsfront.

\section{Om forfatteren}

Håkon Lunde Saxi er førsteamanuensis ved Forsvarets høgskole / Stabsskolen, hvor han forsker og underviser på temaene norsk, nordisk og nordeuropeisk forsvarspolitikk og militærstrategi.

\section{Referanser}

Allison, G. (1969). Conceptual models and the Cuban missile crisis. The American Political Science Review, 63(3), 689-718. https://doi.org/10.2307/1954423

Bogen, O. \& Håkenstad, M. (2015). Balansegang: Forsvarets omstilling etter den kalde krigen. Dreyers forlag.

Bogen, O. \& Håkenstad, M. (2017). Reluctant reformers: The economic roots of military change in Norway, 1990-2015. Defence Studies, 17(1), 23-37. https://doi.org/10.1080/14702436.2016.1256210

Bogen, O. \& Håkenstad, M. (2019). Formålsløs jakt på syndebukker fra Harald Stanghelle. Forsvarets forum. https://forsvaretsforum.no/debatt/formalslos-jakt-pa-syndebukker-fra-harald-stanghelle/109009

Bratberg, Ø. (2019). Statsvitenskapelige blindsoner: Iver Neumann i et faglig perspektiv. Internasjonal Politikk, 77(2), 158-166. https://doi.org/10.23865/intpol.v77.1588

Børresen, J. (2005). Forsvar uten trussel: Det norske Forsvarets rolle og funksjon etter den kalde krigen. Abstrakt forlag.

Børresen, J. (2016). Småstatens forsvars- og sikkerhetspolitikk i en ny tid. I A. Storaker (Red.), Sikkerhetspolitiske veivalg: Skjebnefellesskap med USA og NATO? Progressivt forlag.

Børresen, J., Gjeseth, G. \& Tamnes, R. (2004). Allianseforsvar i endring: 1970-2000 (Bd. 5). Eide Forlag.

Diesen, S. (1999). Forsvarsstudie 2000. Norsk Militcert Tidsskrift, 168(12).

Diesen, S. (2000). Trenger vi en ny strategi? I T. Huitfeldt (Red.), Forsvaret $i$ en ny tid: Utgitt $i$ anledning Oslo Militcere Samfunds 175-års jubileum 1. mars 2000. Oslo Militære Samfund.

Diesen, S. (2010). Foredrag i Oslo Militære Samfund 15. mars 2010: «Hvor går forsvaret? Refleksjoner etter fire år som forsvarssjef». https://oslomilsamfund.no/2010/03/15/foredrag-hvor-gar-forsvaret-refleksjoneretter-fire-ar-som-forsvarssjef/

Diesen, S. (2011). Fornyelse eller forvitring? Forsvaret mot 2020. Cappelen Damm.

Ebbesen, E. (2015, 1. oktober). Et rasert forsvar. Avisa Nordland. https://www.an.no/debatt/kronikk/et-rasertforsvar/o/5-4-184928

Eide, E. B. (1995). En nordisk utenforlands tilpasningsstrategi: Norsk utenriks- og sikkerhetspolitikk i EUs skygge. I I. B. Neumann (Red.), Ny giv for nordisk samarbeid? Norsk, svensk og finsk sikkerhetspolitikk før og etter EUs nordlige utvidelse. Tano.

Forsvarssjefen. (2000). Forsvarssjefens Forsvarsstudie 2000: Sluttrapport. Forsvarets overkommando.

Frantzen, H.-A. (2006, 28. oktober). Gjør hjemmeleksen din Steiro. Aftenposten Morgen. https://www. aftenposten.no/meninger/debatt/i/66egL/gjoer-hjemmeleksen-din-steiro

Friis, K. (2006). The power of the draft: A century of changing legitimacy of Norway's armed forces. I P. Joenniemi (Red.), The changing face of European conscription. Ashgate.

Frisell, E. H., Eriksson, P. \& Jonsson, M. (2018). Norden. I K. Pallin (Red.), Västlig militär förmåga: En analys av Nordeuropa 2017. FOI.

Godal, B. T. (2003). Utsikter. Aschehoug.

Græger, N. (2007). Norsk forsvarsdiskurs 1990-2005:Internasjonaliseringen av Forsvaret [Doktorgradsavhandling]. Universitetet i Oslo.

Græger, N. (2009). Norsk forsvarsdiskurs post-1990. Internasjonalisering og nasjonalt forsvar i nytt samspill. Internasjonal Politikk, 67(3), 351-379.

Græger, N. (2016). Norsk forsvarspolitikk. Territorialforsvar og internasjonal innsats 1990-2015. Spartacus.

Græger, N. (2019). Iver B. Neumann, forsvarsdebatt og fagtradisjon - kritiker, rabulist og nybrottsmann. Internasjonal Politikk, 77(2), 133-139. https://doi.org/10.23865/intpol.v77.1608 


\section{Håkon Lunde Saxi}

Græger, N. \& Leira, H. (2005). Norwegian strategic culture after World War II: From a local to a global perspective. Cooperation and Conflict: Fournal of the Nordic International Studies Association, 40(1), 45-66. https://doi.org/10.1177/0010836705049733

Heier, T. (2000a). Forsvarets utvikling etter den kalde krigen - den vanskelige veien. Norsk Militcert Tidsskrift, 169(3).

Heier, T. (2000b). Forsvarsreformene 2000-2004: Gir Forsvarets politisk uttelling? Institutt for forsvarsstudier.

Heier, T. (2006). Influence and marginalisation: Norway's adaption to US transformation efforts in NATO, 19982004 [Doktorgradsavhandling]. Universitetet i Oslo.

Heier, T. (2019). Et farligere Norge? Fagbokforlaget.

Hilde, P. S. (2020). Norske forsvarsutgifter - en oversikt IFS Insights 10/2020. Institutt for forsvarsstudier.

Holst, J. J. (1967). Norsk sikkerhetspolitikk i strategisk perspektiv. Bind 1: Analyse. Norsk utenrikspolitisk institutt.

Johnsen, G. N., Mølmann, Ø. \& Wessel, E. G. (1993). Brigadenes materiellbetingede operativitet $i$ perioden 199095. Forsvarets forskningsinsitutt.

Jordheim, H. (2010). Diskursanalyse og spørsmålet om historisk endring - fra diskursive nettverk til temporale sjikt. Tidsskrift for kulturforskning, 9(4), 65-79.

Keohane, R. O. (1988). International institutions: Two approaches. International Studies Quarterly, 32(4), 379-396. https://doi.org/10.2307/2600589

Larsen, L. (2011). En ny sikkerhetspolitisk virkelighet. I T. Heier (Red.), Nytt landskap - nytt forsvar: Norsk militcermakt 1990-2010. Abstrakt forlag.

Leira, H. (2004). «Hele vort Folk er naturlige og fødte Fredsvenner». Norsk fredstenkning fram til 1906. Historisk tidsskrift (2), 153-180.

Mevik, L. (1999). Det nye NATO: en personlig beretning. Eide forlag.

Narum, P. (2005, 28. april). Derfor krymper Forsvaret. Aftenposten Morgen.

NATO. (2017). The Secretary General's Annual Report 2016. NATO Public Diplomacy Division.

NATOs stats- og regjeringssjefer. (2010). Active engagement, modern defence: Strategic concept for the defence and security of the members of NATO. NATO.

Neumann, I. B. \& Ulriksen, S. (1997a). Norsk forsvars- og sikkerhetspolitikk. I T. L. Knutsen, G. Sørbø \& S. Gjerdåker (Red.), Norges utenrikspolitikk. Chr Michelsens Institutt/Cappelen Akademisk Forlag.

Neumann, I. B. \& Ulriksen, S. (1997b). Gjenreis forsvarsdebatten! Norsk Militcert Tidsskrift, 16(12), $42-47$.

Njølstad, O. \& Wicken, O. (1997). Kunnskap som våpen: Forsvarets forskningsinstutt 1946-1975. Tano Aschehoug.

Nore, A. (2007). Gud er norsk: Soldatene fra fredsnasjonen. Aschehoug.

NOU 2000: 20. (2000). Et nytt forsvar. Statens forvaltningstjeneste.

Prop. 62 S (2019-2020). Vilje til beredskap - evne til forsvar: Langtidsplan for forsvarssektoren. Forsvarsdepartementet.

Roness, P. G. (1995). Avskjerming, Avskjerming, utfylling, konkurrering og sameining. Noen tankar om strategiar for handtering av teorimangfaldet knytta til organisasjonsendringar. Tidsskrift for samfunnsforskning, 36(2), 178-197.

Saxi, H. L. (2010a). Norwegian and Danish defence policy: A comparative study of the post-Cold War era. Institutt for forsvarsstudier.

Saxi, H. L. (2010b). Defending small states: Norwegian and Danish defense policies in the post-Cold War era. Defense \& Security Analysis, 26(4), 415-430. https://doi.org/10.1080/14751798.2010.534649

Saxi, H. L. (2011). Norsk og dansk forsvarspolitikk etter den kalde krigen: Mellom geopolitikk og strategisk kultur. International Politikk, 69(1), 37-57.

Skogrand, K. (2004). Norsk Forsvarshistorie 1940-1970: Alliert i krig og fred (Bind 4). Eide forlag.

Snyder, G. H. (1984). The security dilemma in alliance politics. World Politics, 36(4), 461-495. https://doi. org/10.2307/2010183

Stanghelle, H. (2019). Det ansiktsløse ansvar. Forsvarets forum, (4), 12-13.

St.meld. nr. 84 (1962-63). Hovedretningslinjer for Forsvarets organisasjon og virksomhet $i$ tiden 1964-68. Forsvarsdepartementet.

St.meld. nr. 22 (1997-98). Hovedretningslinjer for Forsvarets virksomhet og utvikling $i$ tiden 1999-2002. Forsvarsdepartementet.

St.prp. nr. 45 (2000-2001). Omleggingen av Forsvaret $i$ perioden 2002-2005. Forsvarsdepartementet.

St.prp. nr. 42 (2003-2004). Den videre moderniseringen av Forsvaret i perioden 2005-2008. Forsvarsdepartementet. Steiro, Ø. (2006, 20. desember). Diesen er ingen varsler. Aftenposten.

Steiro, Ø. (2019, 2. april). En nasjonal skandale. Nordlys.

Tamnes, R. (1987). Integration and screening: The two faces of Norwegian alliance policy, 1945-1986. I R. Tamnes (Red.), Forsvarsstudier VI: Årbok for Forsvarshistorisk forskningssenter, Forsvarets høgskole. Tano. 
Ulriksen, S. (2002). Den norske forsvarstradisjonen: Militermakt eller folkeforsvar? Pax Forlag.

Ulriksen, S. (2007). Brydningstid - paradigmeskiftet i det norske forsvar (2001-2005). I B. Heurlin (Red.), Nationen eller Verden? De nordiske landes forsvar $i$ dag. Jurist- og Økonomforbundets Forlag.

Ørnhøi, S. (2016). En ny verdensorden? I A. Storaker (Red.), Sikkerhetspolitiske veivalg: Skjebnefellesskap med USA og NATO? Progressivt forlag.

\section{Abstract in English \\ Security Policy, Culture or Defence Economics? Competing Explanations for the Transformation of the Norwegian Armed Forces after the Cold War}

In 2001, the Storting - Norway's parliament - decided on a significant change in Norway's national defence concept and a significant reduction in the defence structure. The Armed Forces' main task should no longer be to constitute a mobilization-based territorial defence force. The decision was a break with the defence concept that had dominated Norwegian defence planning during the Cold War and in the decade that followed. Why was territorial defence abandoned, and what became the Armed Forces' new main task? The article argues that there are three dominant and partly competing explanations for the transformation of the Armed Forces: a security policy explanation, a cultural explanation and an economic explanation. The first approach sees the decision as driven by a desire to contribute more in international operations in order to be perceived as a "good ally" in NATO and the United States. The second explains the transformation with cultural changes among Norwegian decision-makers, through which a new and more "internationalized" defence policy discourse became dominant. The third sees the change as the inevitable result of the financial unsustainability of the old status quo in the Armed Forces.

Keywords: defence policy $\cdot$ defence reform $\cdot$ causal explanation $\cdot$ typologization 